\title{
Pemetaan Bawah Permukaan dan Perhitungan Cadangan Hidrokarbon Formasi Baturaja, Lapangan Mawar, Cekungan Sumatra Selatan
}

\author{
Dina Kusumawardani ${ }^{* 1}$, Yoga Aribowo ${ }^{1}$, Ahmad Syauqi Hidayatillah ${ }^{1}$, \\ Fahri Usmani ${ }^{2}$ \\ ${ }^{1}$ Departemen Teknik Geologi, Fakultas Teknik, Universitas Diponegoro \\ ${ }^{2}$ PT. Medco E\&P Indonesia
}

\begin{abstract}
ABSTRAK
Lapangan Mawar Formasi Baturaja merupakan lapangan yang terletak di Cekungan Sumatra Selatan. Cekungan ini merupakan salah satu cekungan di Indonesia yang memiliki potensi sumber daya hidrokarbon. Studi pemetaan bawah permukaan diperlukan dalam kegiatan eksplorasi untuk mengetahui keadaan geologi dan jebakan minyak melalui data seismik. Tujuan dari penelitian ini untuk mengetahui litologi dan stratigrafi, struktur geologi, dan sebaran reservoir dari data inti batuan dan petrografi, log dan seismik. Kemudian untuk mengetahui fasies karbonat yang ada pada Formasi Baturaja dari analisis fasies seismik dan validasi data inti batuan dan petrografi, dan juga mengetahui cadangan hidrokarbon pada reservoir Baturaja, Lapangan Mawar, Cekungan Sumatra Selatan. Metode penelitian yang digunakan adalah metode deskriptif. Metode ini dilakukan dengan melakukan studi literatur, studi kasus dan analisis data. Analisis yang digunakan adalah analisis kualitatif untuk menentukan jenis litologi, korelasi stratigrafi, korelasi struktural dan analisis data seismik 2D. Analisis data seismik 2D dilakukan dengan picking fault dan picking horizon yang digunakan sebagai dasar interpretasi geologi bawah permukaan dan analisis fasies karbonat pada reservoir Formasi Baturaja, Lapangan Mawar. Berdasarkan dari hasil pengolahan dan analisis data, diinterpretasikan litologi penyusun Formasi Baturaja, Lapangan Mawar yaitu batugamping dari carbonate shelf. Analisis kualitatif, ditemukan zona prospek hidrokarbon pada lapangan Mawar berada pada puncak antiklin dengan perhitungan cadangan yang ada pada reservoir Formasi Baturaja sebesar 188.905.829,38 STB.
\end{abstract}

Kata Kunci: Formasi Baturaja, analisis seismik 2D, perhitungan cadangan.

\begin{abstract}
Mawar Field, Baturaja Formation is located in South Sumatra Basin. This basin is one Indonesia's basin which has a potential of hydrocarbon. The study of subsurface mapping is a needed on exploration activity in oil and gas companies because by doing a subsurface mapping, it can be shown geological condition and an oil trap from seismic data. The purpose of this research is to understanding the litology and its stratigraphy, the geological structure and reservoir distribution from core and petrography data, log and seismic data. Then to understanding the carbonate facies on Baturaja Formation by analyze seismic facies and validate core and petrography data, and also to understanding the hydrocarbon reserve on Baturaja Formation of reservoir Mawar Field, South Sumatra Basin. The research methods used are descriptive method. Descriptive method is a method which is held by doing a research on the literature, case studies based on, and data analysis on the thesis topics. Qualitative analysis was conducted to determine the type of lithology, stratigraphic, structural correlation and analysis seismic $2 D$. The analysis of $2 D$ seismic was carried out in the form of picking fault and picking horizon which is used as the core for interpretation of the subsurface geology and analysis of carbonate facies at reservoir of Baturaja Formation in the Mawar Field. Based on the results of the data analysis and interpretation, the lithology of Baturaja Formation in the Mawar field is limestone as a carbonate shelf deposition. Based on qualitative analysis, it discovered hydrocarbon prospects in the Mawar field is at the top anticline with the preserve estimation that exist in the Baturaja Formation reservoir by 188,905,829.38 STB.
\end{abstract}

Keywords: Baturaja Formation, 2D seismic analysis, preserve estimation.

*) Korespondensi : aliesyahbanadina@gmail.com 
PENDAHULUAN

Produksi minyak dan gas bumi harus diimbangi dengan adanya kegiatan eksplorasi potensi cadangan minyak dan gas bumi baru dalam memenuhi kebutuhan energi. Kegiatan eksplorasi berkelanjutan seperti eksplorasi hidrokarbon harus dilakukan dengan mengintegrasikan aspek geologi dan geofisika sehingga menghasilkan informasi yang komprehensif, terutama kondisi bawah permukaan untuk menemukan potensi sumberdaya minyak dan gas bumi yang baru. Peta bawah permukaan dibangun dan didukung analisis $\log$ geofisika dapat digunakan untuk melakukan identifikasi zona prospek minyak dan gas bumi, distribusi fasies batuan, dan akumulasi minyak dan gas bumi.

Tujuan dari penelitian ini adalah untuk mengetahui litologi dan stratigrafi, struktur geologi, dan distribusi reservoir dari sampel inti batuan (core) dan petrografi, log dan seismik di Lapangan Mawar. Penelitian ini juga bertujuan untuk menentukan fasies karbonat yang ada pada Formasi Baturaja Lapangan Mawar, serta menge-tahui cadangan hidrokarbon yang ada pada reservoir Formasi Baturaja,
Lapangan Mawar, Cekungan Sumatra Selatan.

\section{Geologi Regional}

Daerah penelitian Lapangan Mawar terletak pada Musi Platform yang terletak di Cekungan Sumatra Selatan (Gambar 1). Daerah penelitian merupakan tinggian yang terbentuk pada Miosen Awal, dengan rekaman stratigrafi ditunjukkan pada Gambar 2. Musi platform semakin turun diakibatkan oleh pengangkatan di barat bersamaan dengan volcanic arc. Di bagian selatan platform terdapat Lematang trough dan di bagian tengah platform merupakan Busur High dari elongated paleohigh yang melebar dari timur laut.

Daerah penelitian terdiri dari batuan dasar (basement), Formasi Baturaja dan Formasi Telisa. Menurut Ginger dan Fielding (2005), batuan dasar Cekungan Sumatra Selatan terdiri dari pertemuan kompleks antara batuan beku Mesozoikum, batuan metamorf Paleozoikum-Mesozoikum, dan batuan sedimen. Batuan dasar yang paling tua diperkirakan merupakan bagian dari lempeng mikro Malaka yang membentang di bagian utara dan selatan Cekungan Sumatra Selatan.

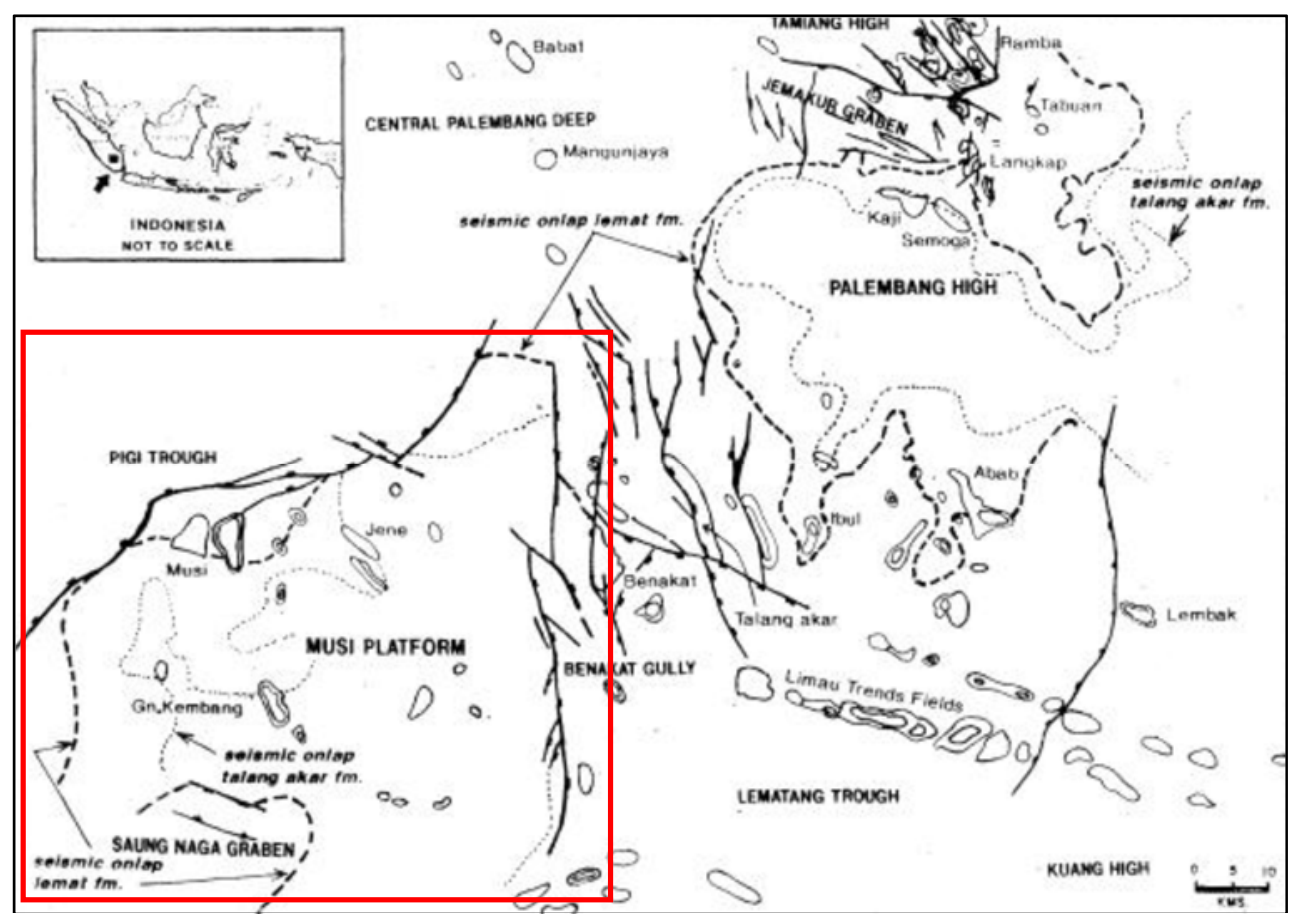

Gambar 1. Kerangka tektonik yang terbentuk pada area Lapangan Mawar ditandai kotak merah (Rashid dkk., 2006). 


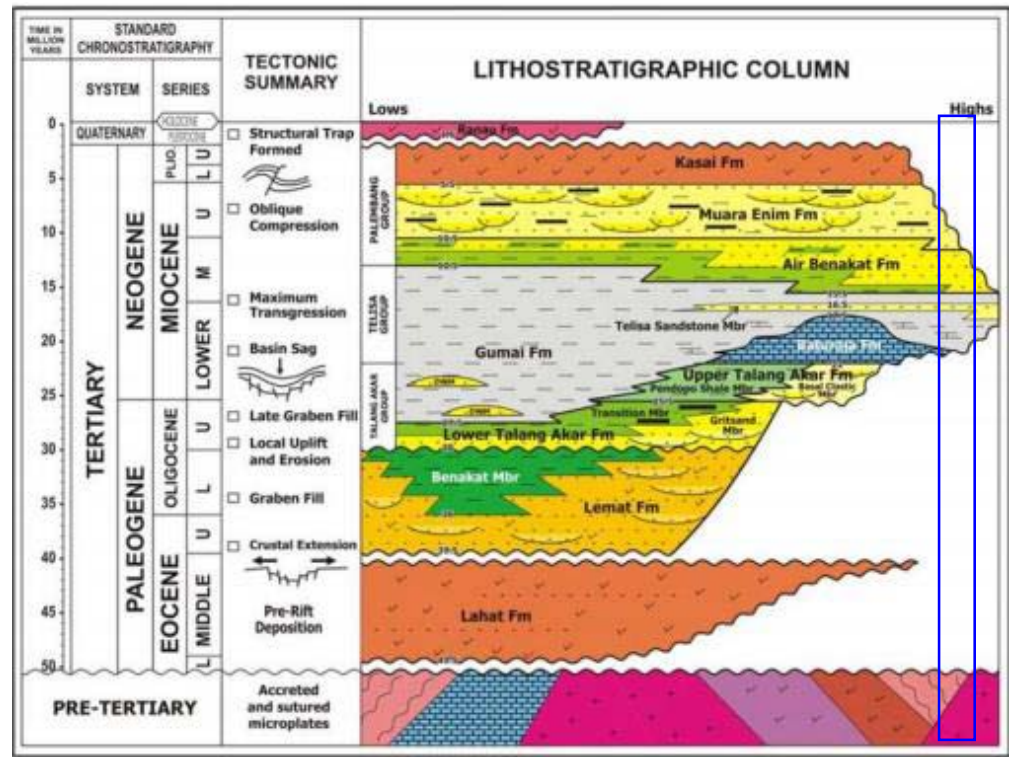

Gambar 2. Cakupan kolom stratigrafi daerah penelitian tercakup di dalam kotak biru. (Kamal, 2005 dalam Medco, 2012).

Pada bagian selatan terdapat sisa-sisa deformasi lempeng mikro Mergui. Lempeng mikro Malaka dan Mergui ini dipisahkan oleh kumpulan Mutus, fragmen terdeformasi yang muncul akibat tumbukan. Morfologi batuan dasar tersebut dipercaya mempengaruhi morfologi rift Eosen-Oligosen dan proses inversi/ strikeslip pada Plio-Plistosen, hal ini dibuktikan dengan keberadaan karbondioksida dalam gas hidrokarbon maupun saat ekstensi pada rekahan dalam batuan dasar.

Formasi Baturaja diendapkan pada Miosen Awal menumpang tidak selaras diatas batuan Pra-Tersier atau diatas Formasi Talang Akar. Di bagian atas formasi terdiri dari batuan karbonat sedangkan bagian bawah umumnya merupakan serpih dengan lapisan tipis batugamping. Ketebalan Formasi ini berkisar antara 76-120 m, dijumpai pula ketebalan 20-120m yang diakibatkan oleh relief topografi yang tidak teratur dari batuan Pra-Tersier. Transgresi berlangsung menerus hingga Miosen Awal dengan pengendapan serpih di sekitar graben sedangkan kondisi laut dangkal di sekitar tinggian masuk ke cekungan atau intrabasinal dan sebagian besar menuju ke bagian timur cekungan. Produksi karbonat yang pesat terjadi pada saat ini dan menghasilkan pengendapan batugamping baik di bagian platform dari tepi cekungan maupun di bagian tinggian sebagai terumbu masuk cekungan atau intrabasinal. Reservoir karbonat berkualitas tinggi umum dijumpai di bagian selatan cekungan, namun lebih sedikit di SubCekungan Jambi di Utara Cekungan. Porositas sekunder berkembang ke arah selatan dan timur (Ginger dan Fielding, 2005).

Formasi Telisa terbentuk pada lingkungan laut dalam menuju lingkungan transisi yang berumur Miosen AwalMiosen Tengah (Ginger dan Fielding, 2005).Formasi ini terdiri dari litologi berupa serpih fossiliferous, batulanau, batupasir halus dan sedikit pengendapan karbonat yang mengandung gaukonit. Formasi ini memilki ketebalan berkisar antara 1800-2700 m. Selama puncak transgresi, pengendapan serpih glaukonitan mendominasi di seluruh cekungan dan membentuk batuan penyekat regional. Selanjutnya, progradasi endapan delta di seluruh cekungan terjadi dan selanjutnya endapan ini digantikan oleh endapan transisi dan kemudian oleh endapan serpih laut. Daerah-daerah platform dibagian timur dan timur laut merupakan daerah asal sedimen meskipun demikian pada saat ini sedimen vulkaniklastik juga bersumber dari tinggian vulkanik di bagian barat. 


\section{METODE PENELITIAN}

Penelitian menggunakan data sekunder yang terdiri dari sampel inti batuan, petrografi, log geofisika (GR, ILD, RHOB, NPHI) dari 3 sumur : Mawar-1, Mawar-2, Mawar-3, dan 18 penampang seismik 2D. Penelitian ini diawali dengan studi literatur terkait geologi regional lapangan, serta dilanjutkan deskripsi sampel inti batuan dan petrografi. korelasi log sumur dan pemetaan bawah permukaan menggunakan Petrel 2013.

\section{HASIL PENELITIAN \\ Sampel Inti Batuan dan Petrografi}

Deskripsi inti batuan dan petrografi dilakukan untuk menentukan litologi penyusun serta litofasies karbonat Formasi Baturaja, Lapangan Mawar, baik secara megaskopis maupun mikroskopis pada sampel target batuan. Deskripsi inti batuan dilakukan pada sampel dari interval kedalaman 638-646 m, 640-646 m, dan 647-652 m (Gambar 4). Analisis petrografi dilakukan pada sampel dari kedalaman 638 $\mathrm{m}, 641 \mathrm{~m}, 646 \mathrm{~m}, 646 \mathrm{~m}, 649 \mathrm{~m}$, dan 650 $\mathrm{m}$ (Gambar 3). Berdasarkan analisis inti batuan dan petrografi dari sumur Mawar-2, litologi penyusun Formasi Baturaja adalah Packstone dan Wackstone.

\section{Litologi dan Lingkungan Pengendapan} Log GR, ILD, dan NPHI dari semua sumur mengidentifikasi batupasir, serpih, dan batugamping, hanya Mawar-1 yang tidak menembus batuan dasar.

Analisis elektrofasies hasil rekaman $\log$ gamma ray (GR) memperlihatkan konfigurasi log cylindrical pada interval batugamping. Pola ini menunjukkan pengendapan batugamping dengan suplai sedimen konstan (agradasi) yang merupakan penciri endapan carbonate shelf (Kendall, 2005).

\section{Korelasi Log Sumur}

Penampang korelasi log sumur berarah Utara-Selatan dibuat dengan urutan sumur : Mawar-2, sumur Mawar 1 dan sumur Mawar-3 (Gambar 5), log digantung pada MFS. Korelasi log sumur menunjukkan distribusi Formasi Baturaja di daerah penelitian semakin menebal ke arah selatan.

\section{Analisis Data Petrofisik}

Nilai porositas dan saturasi air dari data petrofisik sumur merupakam sebagian variable yang digunakan untuk menentukan cadangan hidrokarbon pada reservoir secara empiris. Porositas rata-rata reservoir adalah 0,28 untuk cut off porositas sebesar 0,13 yang diperoleh dari nilai porositas efektif rata-rata setiap sumur pada Lapangan Mawar (Tabel 1). Berdasarkan klasifikasi Koesoemadinata (1980), porositas reservoir target di Lapangan Mawar tergolong sangat baik hingga istimewa.

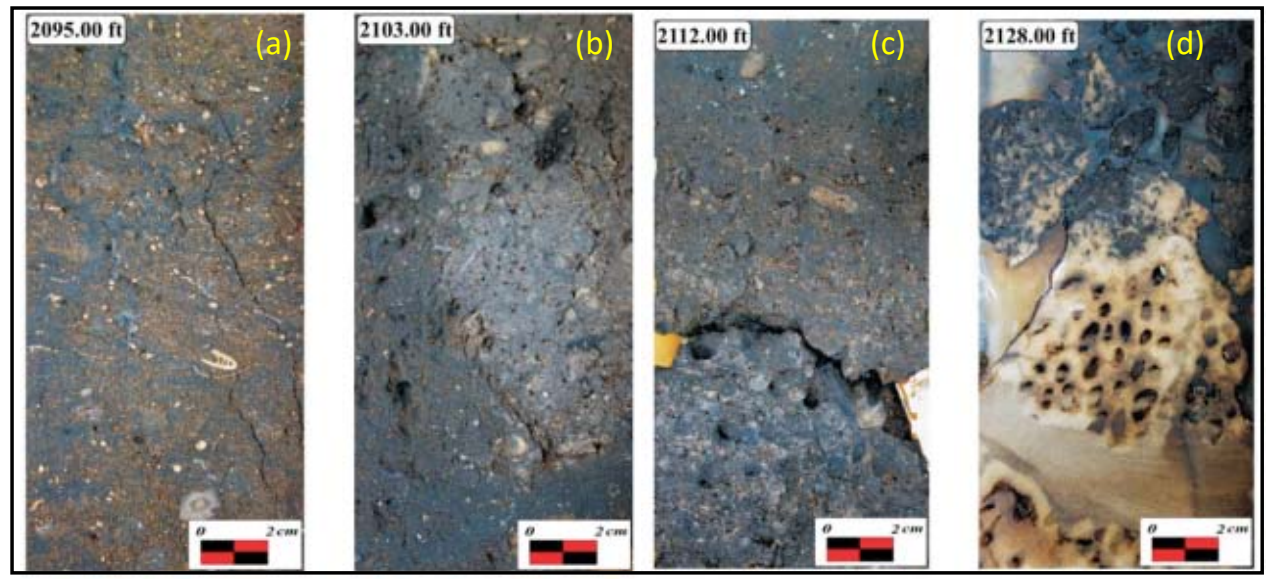

Gambar 3. Inti Batuan Mawar-2; (a) Molluscs Wackstone-Packtone; (b) Molluscs WackstonePacktone ; (c)Echinoderms Wackstone; (d) Coral Wackstone-Floatstone(Medco, 2012). 


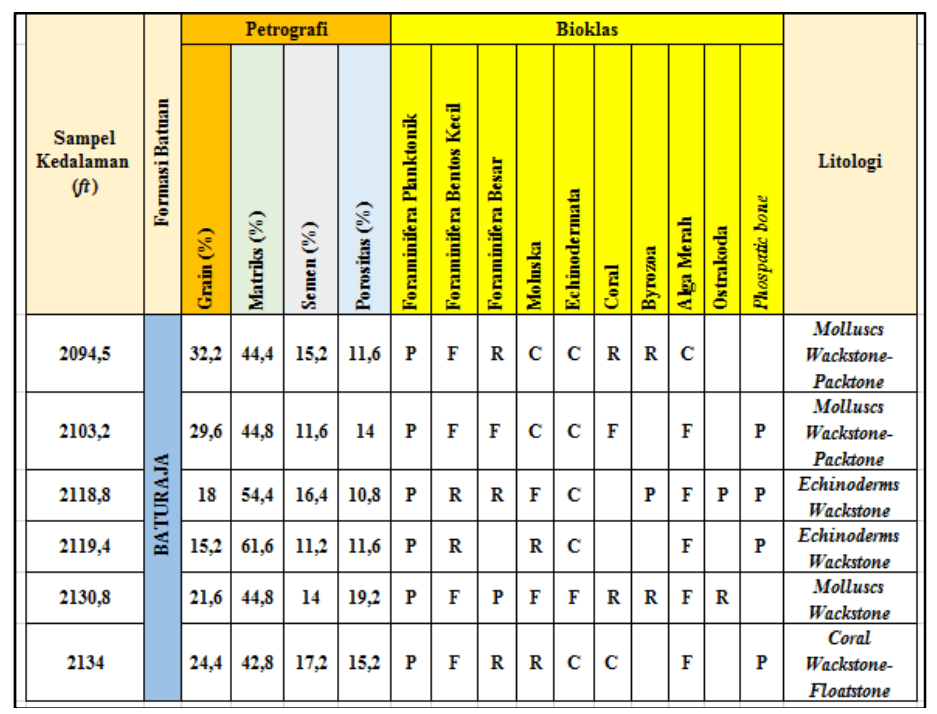

Gambar 4. Data Inti Batuan dan Petrografi Mawar-2 (Medco, 2012 dengan modifikasi).

Tabel 1 Nilai Rata-rata Porositas Efektif.

\begin{tabular}{lc}
\hline Sumur & Porositas rata-rata \\
\hline Mawar-1 & 0,22 \\
Mawar-2 & 0,309 \\
Mawar-3 & 0,27 \\
\hline
\end{tabular}

\section{Interpretasi Penampang Seismik}

Well seismic tie (Gambar 6) dilakukan untuk mengikat horison seismik yang memiliki domain waktu dengan data sumur yang memiliki domain kedalaman sehingga dapat diketahui kedudukan horison seismik pada kedalaman sebenarnya.
Penelusuran horison dan struktur dilakukan untuk 3 top formasi yakni batuan dasar (horison merah) yang juga menjadi bottom Formasi Baturaja, top Formasi Baturaja (horison biru), dan top Formasi Telisa (horison hijau). Struktur geologi yang dominan teramati pada penampang seismik di Lapangan Mawar adalah sesar normal (Gambar 7). Selanjutnya, peta struktur kedalaman diperoleh dari hasil nilai perkalian antara nilai kecepatan rata-rata (average velocity) dari log sumur dengan nilai TWT (two way time) dari peta struktur waktu masing-masing top formasi.

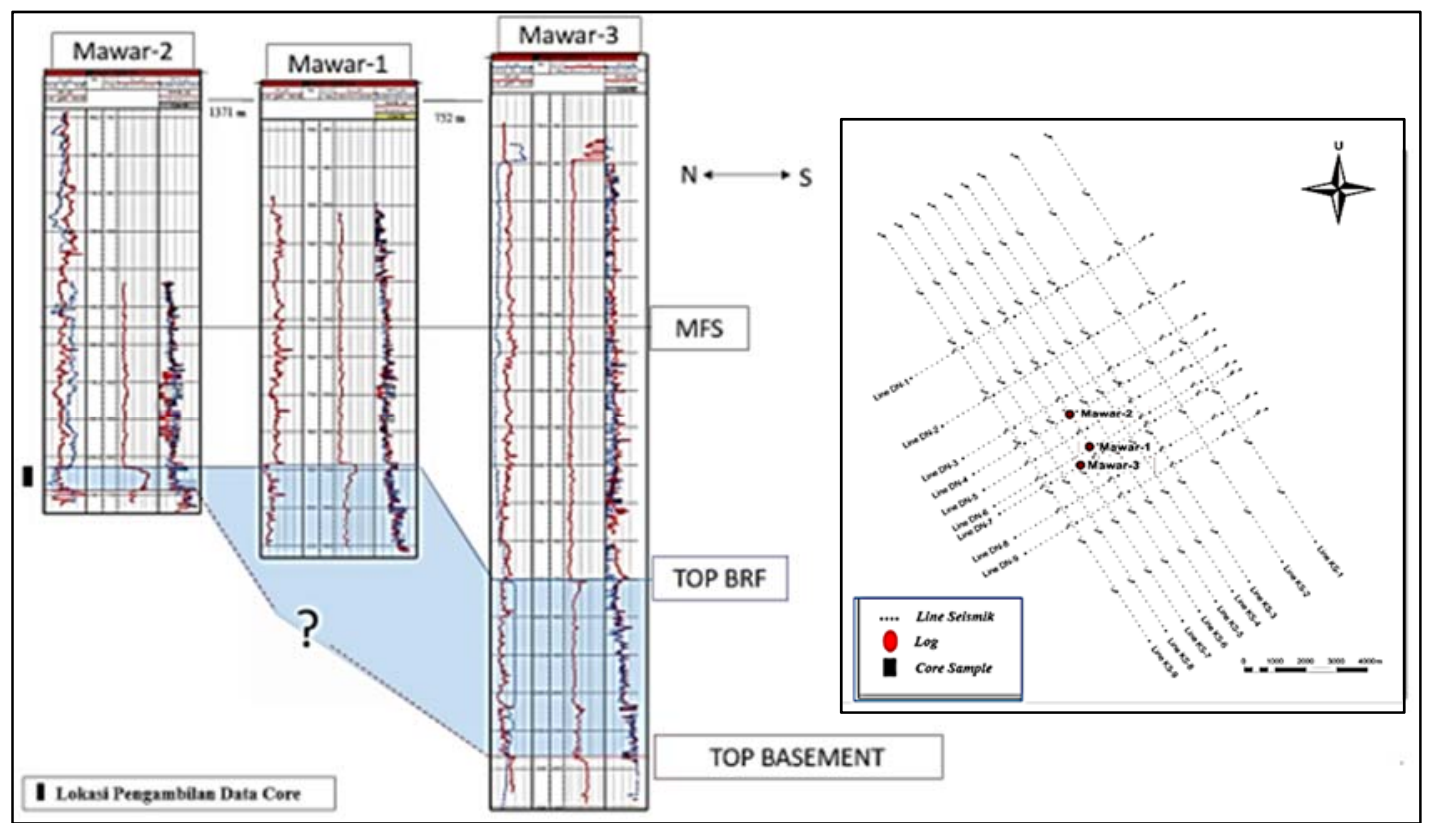

Gambar 5. Korelasi Stratigrafi berdasarkan kesamaan pola gamma ray 


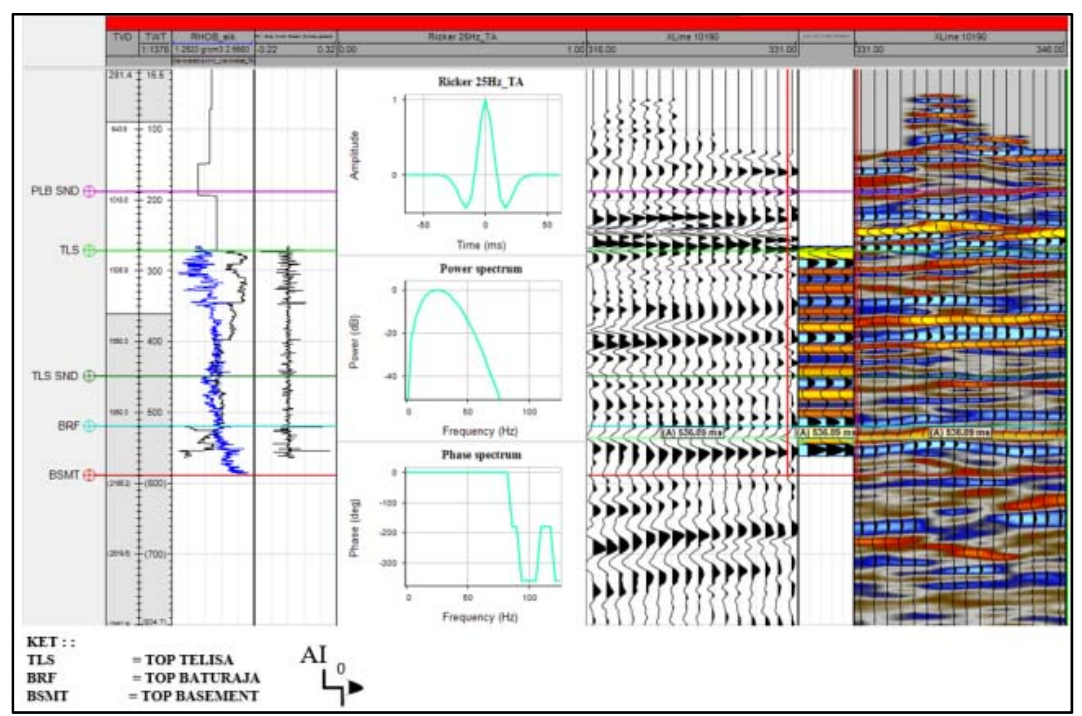

Gambar 6. Well seismic tie, sumur Mawar-1 terhadap line seismik KS-6.

\section{PEMBAHASAN}

Sampel inti batuan dari 3 sumur di Lapangan Mawar mengindikasikan pola terumbu keep up. Hal tersebut menjelaskan laju kenaikan muka laut relatif sama dengan laju pertumbuhan terumbu. Interpretasi penampang seismik pada Lapangan Mawar menunjukkan geometri terumbu pada interval Formasi Baturaja. Interval yang dominan tersusun dari mudstone, wackstone dan packstone yang dominan dapat diinterpretasikan sebagai hasil sedimentasi pada low relief basement.

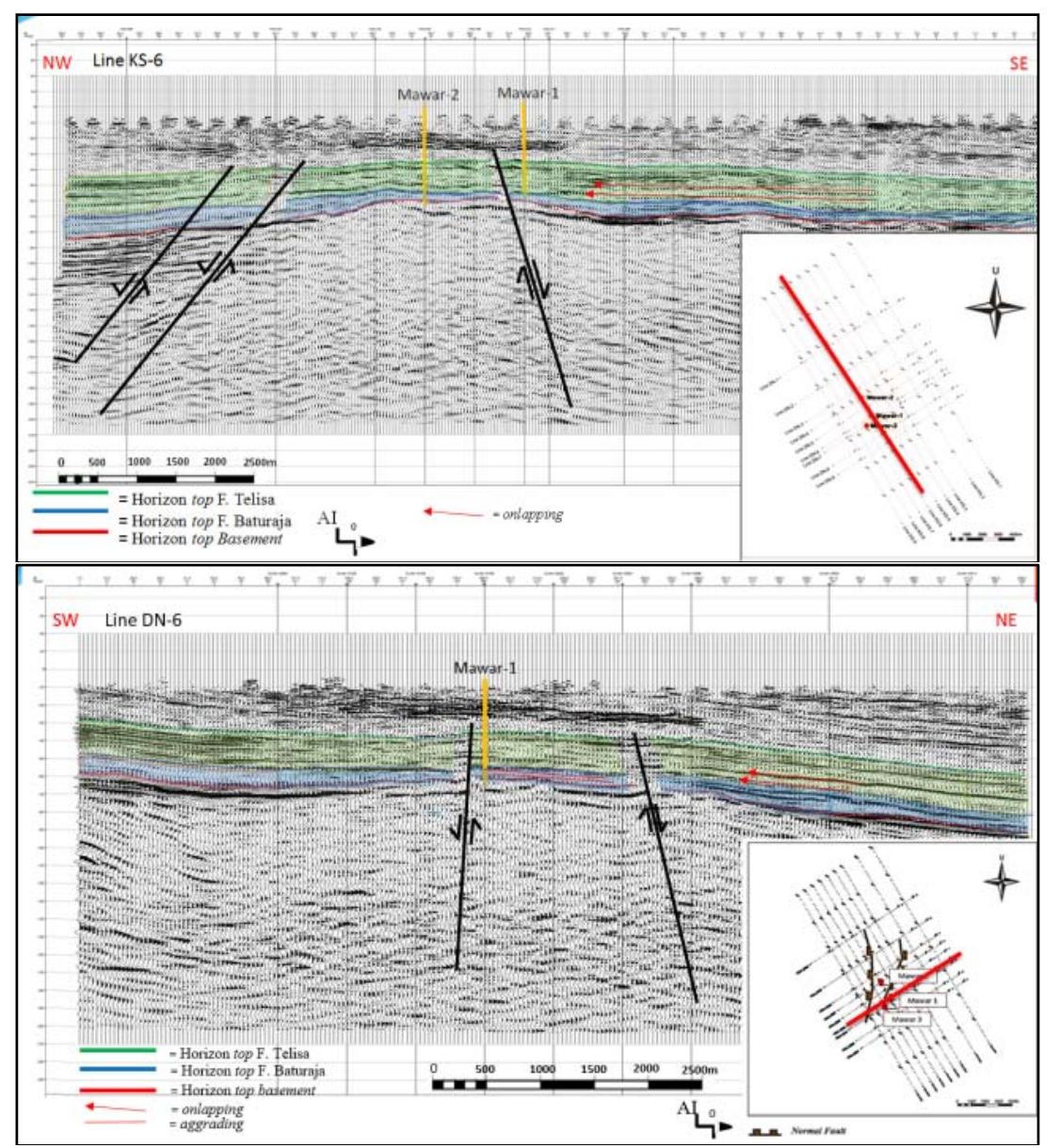

Gambar 7. Interpretasi penampang seismik line KS-4 (atas) dan line DN-6. 
Low-relief carbonate mud-bank sendiri berkembang dengan baik di back-arc dan foreland basin yang terlindung atau jauh dari open sea, seperti di cekungan Sumatra Selatan.

Peta ketebalan Formasi Baturaja menunjukkan pola penebalan formasi yang memanjang ke arah utaratimurlautselatanbaratdaya pada daerah penelitian (Gambar 8). Hal tersebut menunjukkan kontrol sesar yang berpengaruh terhadap distribusi formasi target. Berdasarkan identifikasi seismik dan pembuatan peta bawah permukaan diidentifikasi daerah penelitian pada Lapangan Mawar struktur geologi yang berkembang berupa struktur sesar normal yang membentuk berarah timurlaut-baratdaya yang berdasarkan geologi regional sesar tersebut terbentuk pada fase ekstensional. struktur geologi sesar normal pada Cekungan Sumatra Selatan terbentuk pada megasikuen syn-rift yang menurut Ginger dan Fielding (2005).

Pada Miosen Awal, Sumatra Selatan mengalami rotasi sebesar 15 derajat searah dengan jarum jam hingga membentuk graben dengan arah utaratimurlautselatanbaratdaya.

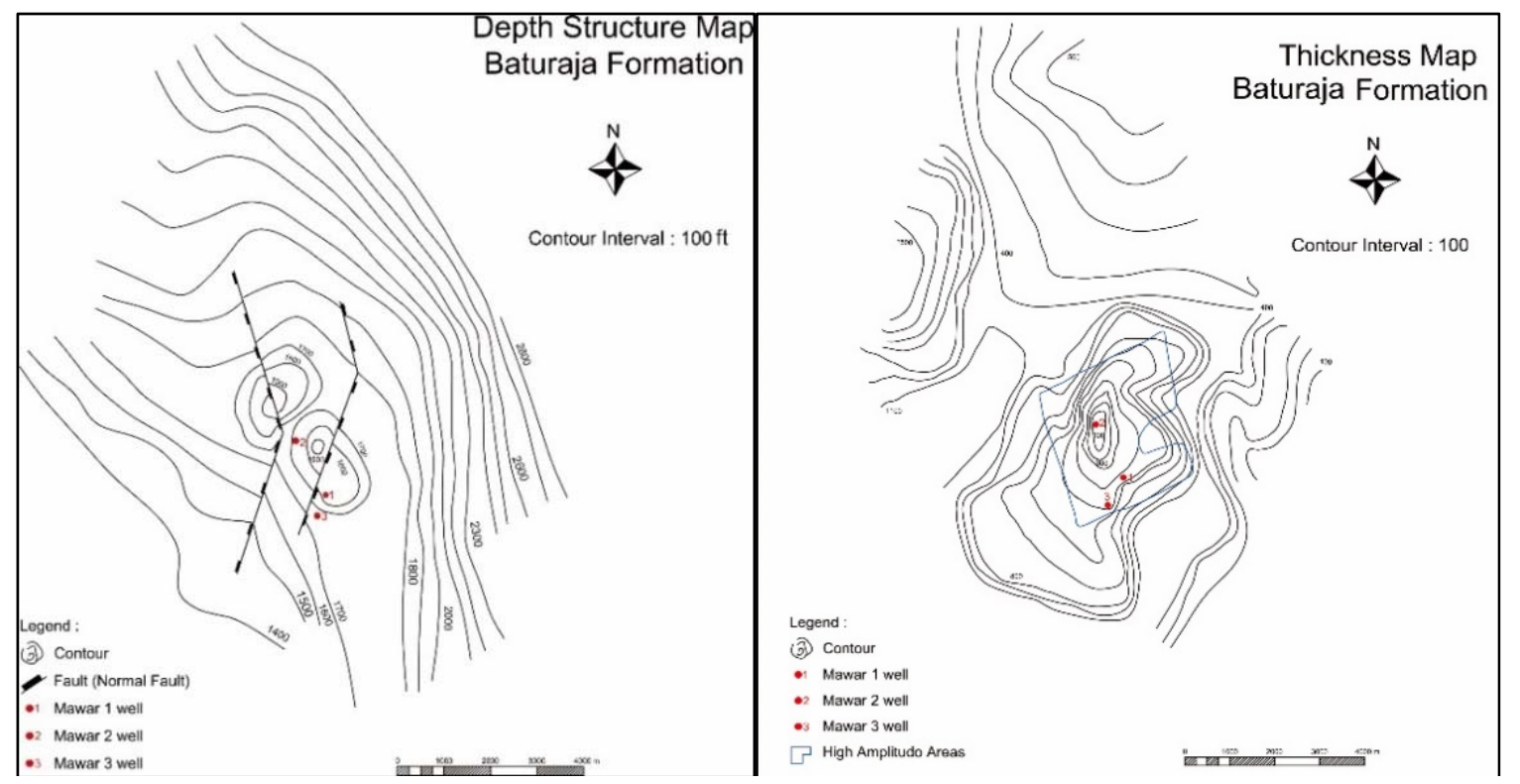

Gambar 8. Peta struktur kedalaman top Formasi Baturaja (kiri). Peta ketebalan Formasi Baturaja (kanan) menunjukkan distribusi formasi yang berarah utara timurlaut - selatan baratdaya.

\section{Perhitungan Cadangan Hidrokarbon}

Penentuan zona prospek hidrokarbon terlebih dahulu ditentukan dari formasi target reservoir, yaitu Formasi Baturaja. Zona prospek dibatasi oleh kontak air formasi dengan minyak (oil water contact) yang ada pada reservoir. Oil water contact ditentukan berdasarnilai $\log$ resistivitas (LLD) yang rendah serta melihat separasi (crossover) $\log$ neutron dengan $\log$ densitas. Nilai OWC ini didapat dari data sekunder perusahaan yang sudah diindentifikasi yakni pada kedalaman 1738 $f t$. Peta stuktur kedalaman Formasi Baturaja, zona prospek dibatasi oleh kontur berwarna hijau putus-putus yang merupakan batas dari OWC (Gambar 9). Zona prospek hidrokarbon pada daerah penelitian berdasarkan peta bawah permukaan yang dihasilkan terletak pada 2 puncak antiklin yang teresarkan.

Setelah pembuatan peta struktur kedalaman kemudian diberi batas dengan OWC (oil water contact). Kontur yang dihitung volumenya adalah kontur yang memiliki trap dan dibatasi oleh OWC (oil water contact).

Mengacu pada dasar teori menurut Lucia (2008), perhitungan volume menggunakan metode pyramidal untuk rasio luas kontur $<0,5$ dan trapezoidal untuk nilai rasio luas kontur $>0,5$. 


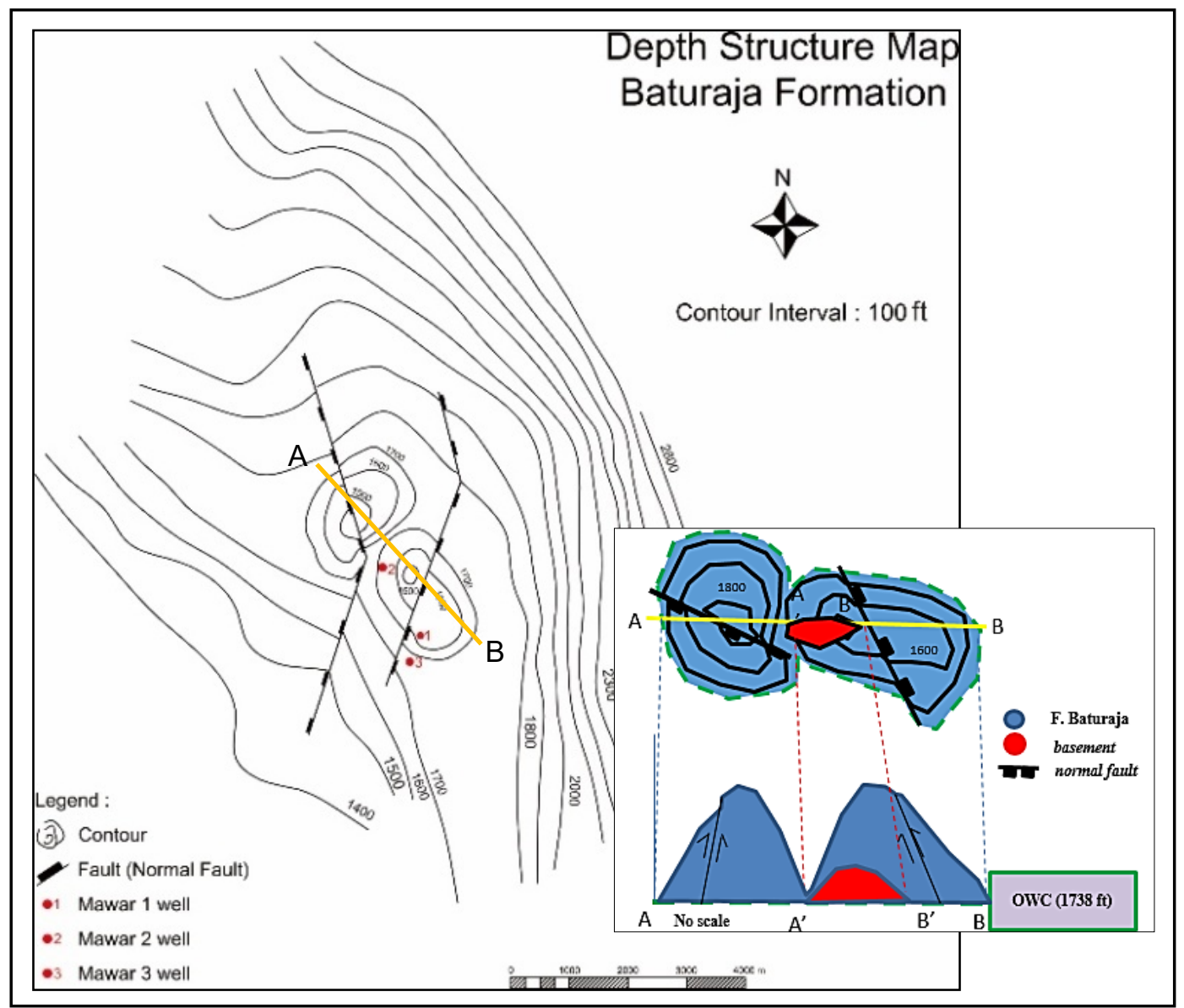

Gambar 9. Perhitungan bulk volume reservoir dengan oil water contact pada level 1.738 kaki.

Tabel 2. Rekapitulasi Perhitungan Cadangan Hidrokarbon.

\begin{tabular}{ccccc}
\hline Porositas & Saturasi Air & $\begin{array}{c}\text { Volume } \\
(\text { acre. } f \text { t })\end{array}$ & Net to gross & $\begin{array}{c}\text { Boi } \\
(\mathrm{bbls})\end{array}$ \\
\hline 0,28 & 0,33 & $154.356,80$ & 0,9 & 1,0703 \\
\hline
\end{tabular}

Volume Formasi Baturaja dikurangi dengan hasil volume pada batuan dasar untuk memperoleh volume reservoir. Volume reservoir didapatkan dengan mengurangi nilai volume baturaja hingga OWC dengan volume batuan dasar hingga OWC. Didapatkan nilai volume reservoir sebesar 154.356,80 acre.feet (Gambar 9).

Parameter petrofisik yang digunakan untuk menghitung cadangan adalah nilai rata-rata porositas dan saturasi air. Selanjutnya nilai-nilai tersebut disubstitusi ke dalam persamaan 2.4 (Rubiandini, 2004) :

$$
\mathrm{IOIP}=\frac{V b x \phi x(1-S w)}{B o i} \times 7758 B b l
$$

keterangan :

IOIP = initial oil in place, $(\mathrm{STB}$, stock tank barrels).

$\mathrm{Vb}=$ volume bulk reservoir, acre-feet .

$\Phi=$ Porositas, $(\%$ atau desimal $)$.

Sw = Saturasi air, (\% atau desimal).

$7758=$ Faktor konversi acre.ft ke barrels.

Boi = oil formation volume factor (STB/bbls).

Peta struktur ketebalan yang dibuat masih termasuk ketebalan shale, sehingga perhitungan cadangan perlu dikalikan dengan nilai net to gross sebesar 0,9 yaitu nilai yang disepakati oleh perusahaan berdasarkan data sumur dan seismik. Hasil perhitungan cadangan dapat dilihat pada Tabel 2. 
Hasil perhitungan empiris menyebutkan bahwa Lapangan Mawar memiliki cadangan minyak mula-mula (initial oil in place) sebesar 188.905.829,38 STB.

\section{KESIMPULAN}

Formasi Baturaja Lapangan Mawar adalah batugamping yang merupakan endapan carbonat shelf pada half-graben berarah utara timurlaut - selatan baratdaya. Geometri Formasi Baturaja membentuk antiklin yang memanjang ke arah utaratimurlaut-selatanbaratdaya. Hasil perhitungan estimasi menyebutkan bahwa cadangan pada zona prospek di interval Formasi Baturaja Miosen Awal adalah sebesar 188.905.829,38 STB.

\section{UCAPAN TERIMAKASIH}

Penulis mengucapkan terimakasih kepada PT. Medco E\&P Indonesia yang telah memberikan kesempatan penulis mengolah data Tugas Akhir di perusahaan melalui bimbingan dari mentor perusahaan.

\section{DAFTAR PUSTAKA}

Ginger, D. dan Fielding, K. 2005. The Petroleum Systems and Future Potential of The South Sumatra Basin. Proceeding Indonesian Petroleum Association (IPA), The 30 ${ }^{\text {th }}$ Annual Convention \& Exhibition, Jakarta.

Kendall, C. G. 2005. Stratigraphy and Sedimentary Basin. University of South Carolina.

Koesoemadinata, R. P. 1980. Geologi Minyak dan Gas Bumi, jilid I dan II. ITB : Bandung.

Longman, M.W. 1981. A Process Approach to Recognizing Facies of Reef Complexes. SEPM Special Publiction.

Lucia, F. J. 2008. Carbonate Reservoir Characterization: An Integrated Approach 2ndEdition, Springer-Verlag Berlin Heldenberg, Berlin, Germany.

Medco E\&P Indonesia, 2012. Internal Report, Jakarta (tidak dipublikasikan).

Rashid, Sosrowidjojo, dan Widiarto, 2006. Musi Platform and Palembang High: A New Look at the Petroleum System. Proceeding Indonesian Petroleum Association, The $26^{\text {th }}$ Annual Convention \& Exhibition, Jakarta.

Rubiandini. 2004. Drilling Fluid Design and Solid Control Course, Bandung. 